\title{
A MAGYAR BANKRENDSZER FELNÖTTÉ VÁLÁSÁNAK TÖRTÉNETE
}

Várhegyi Éva

A három évtizeddel ezelőtt újjászülető magyar bankrendszer jelentős változásokon ment keresztül az emberöltőnyi idő alatt. Fejlődését sokféle genetikai hiba és szerzett betegség gátolta, és a külső környezete sem volt mindig „barátságos” hozzá; emiatt időnként megtorpanások, sőt visszaesések is tarkították a pályáját. Ennek ellenére nagyrészt megszabadult rossz örökségeitől, a kamaszkori átváltozások (privatizáció) nehézségein is túltette magát, és a felnőttkorba lépésekor, a nemzetközi hitelválság nyomán rázúdult nehézségeket is többé-kevésbé átvészelte.

A cikkben a magyar bankszektor 30 éves fejlődésének meghatározó állomásait tekintjük át. A kétszintű bankrendszer kialakulását, a kedvezőtlen örökségeket részben korrigáló bankkonszolidációt, a privatizációs döntés nehézkes, politikával átszőtt folyamatát, a tulajdonosi struktúrában külföldi dominanciát eredményező bankeladásokat, a sokféle gúzsból kiszabadult bankok nekiiramodását és versengését, a vágtát megfékező válságot és végül a 2010-ben színre lépő kormány „nemzeti” bankpolitikáját, amely újra felerősíteni látszik a korábban már leépített erkölcsi kockázatot.

JEL-kódok: D43, Go1, G21, N24

Kulcsszavak: bankrendszer, privatizáció, verseny, válság

\section{FOGANTATÁS - GENETIKAI HIBÁKKAL}

A piacgazdasághoz illeszkedő, kétszintű bankrendszernek a politikai rendszerváltást pár évvel megelőző, 1987-es „fogantatásakor” nem lehetett levetni a múlt örökségeit. A beépített érdekkonfliktust hordozó tulajdonosi háttér, a politikai nyomásgyakorlás lehetősége, a szabályozás gyengesége és a bankvezetőket hajszoló növekedési láz már önmagában is elég lett volna ahhoz, hogy a három MNButódbank elkerülhetetlenül válságba araszoljon. A nyolcvanas-kilencvenes évek fordulóján szerzett betegségek mellett azonban hosszan ható örökségek, ha tetszik, genetikai hibák is terhelték ezeket a bankokat. A gyenge lábakon álló ügyfelek és a korábban még az MNB által nyújtott, a megtérülés kevés esélyével kecsegtető hitelek mellett a tőkehiány terhe is húzta rosszul összeállított úti batyujukat. Az MNB-ből leválasztott kereskedelmi bankok, a Magyar Hitel Bank (MHB), az 
Országos Kereskedelmi és Hitel Bank (OKHB) és a Budapest Bank (BB) megkapták a korábbi hitelezési részlegek hitelállományát és a forrásul szolgáló, refinanszírozási hitelkereteket. Tőkeellátásukat azonban másodlagos kérdésként kezelték. 1987-ben a három utódbank együttesen alig 20 milliárd forint alaptőkével rendelkezett, miközben kihelyezéseik együttes összege elérte a 450 milliárd forintot. A következő években részben alaptőke-emelések, részben a felhalmozott vagyon és a tartaléktőke növekedése nyomán csökkent ugyan az áttételi arány, de a bankok 44 milliárd forintra duzzadt tőkéje sem illeszkedett a kihelyezésekben rejlő kockázat mértékéhez. A pénzügyi kormányzat maga is rontott a helyzeten: 1989-ben megszüntette azt a lehetőséget, hogy ráfordításként számolhassák el a kockázati céltartalékokat. A rövidlátó fiskális politika hatása a kilencvenes évek bankválságaiban csapódott le, és jócskán megnövelte a mentési költségeket.

$\mathrm{Az}$ utódbankok később manifesztálódott tőkeproblémái csak részben következtek abból, hogy 1987-ben nem kaptak elegendő tőkét. A hiányosságot tovább erösítette a bankok ügyfeleinek gyenge tőkehelyzete, amelynek oka az 1968-as féloldalas reformig nyúlik vissza, amikor a többé-kevésbé önállósított vállalatok tőkehiányát az MNB forgóalappótló hitelei hidalták át, amelyek mintegy állandó elemként épültek be a vállalatok forrásaiba. Az eladósodott ügyfélkör és a bankok tőkehiánya olyan örökség volt, amelyből gondok fakadtak, s ezek az évek során tovább eszkalálódtak.

A magyar gazdaság összehúzódása, a transzformációs visszaesés jeleinek felbukkanása már a rendszerváltás előtt megkezdődött (Kornai, 1993). A GDP 15 százalékkal csökkent 1988-1991 között, és ebben még a belső bajok játszották a döntő szerepet, amit csak felerősített a keleti piacoknak a rendszerváltást kísérő összeomlása. A gazdaság zsugorodásával felszínre kerülő és súlyosbodó problémákat az utódbankok belső gyengeségei is felerősítették. Az újonnan kialakított bankok szervezeti-irányítási rendszere és döntési mechanizmusa sem volt megfelelő a megfontolt üzleti döntések meghozatalához. A banki menedzsmentek gyakorlatilag teljhatalmúak voltak, mivel az igazgatóságok és felügyelőbizottságok ellenőrző szerepe általában formális volt. A belső és a bankközi információs rendszerek gyengeségei is hozzájárultak a rossz döntésekhez. A belső döntési mechanizmusokhoz gyakran nem kapcsolódott megfelelő felelősségi rendszer, és a belső szabályzatok (adósminősítés, hitelezési és befektetési kézikönyvek stb.) is hiányoztak. A bankok belső gyengeségei és nem megfelelő érdekviszonyai hozzáadódtak azokhoz az örökségekhez, amelyek a következetlen bankreformból származtak.

Az MNB-utódbankokba a teremtésükkor beprogramozott tőkevesztések és az örökölt rossz hitelek csak kisebb részben voltak felelösek a kilencvenes évek elejére kialakult, súlyos helyzetért. ${ }^{1}$ Nem lehet eltekinteni egyes bankvezetők hazárd

1 Becslések szerint a rossz hitelek harmada az MNB-ből átvett, még le nem járt vagy átütemezett hitelállományból származott (vö. VÁRHEGYI, 1995). 
üzletpolitikájától sem, ami nemcsak az utódbankokat, de az újonnan alapított, kellő mértékű tulajdonosi ellenőrzés nélkül müködő bankokat is jellemezte. Akkoriban csak azok az intézmények müködtek megfelelő kontroll alatt, amelyekben külföldi bankok voltak a meghatározó tulajdonosok.

A szocialista gazdaságokra jellemző növekedési hajsza öröksége a rendszerváltás után is fennmaradt ott, ahol nem érvényesült kemény tulajdonosi ellenőrzés, és ahol a vezetők egyedüli sikermutatója a bank gazdasági súlya és a papíron kimutatható, bár a valóságostól mind távolabb álló nyereség maradt. Hogy a banki kihelyezések jelentős része a megtérülés reményével sem kecsegtetett, jól mutatja a bankok tevékenységének a gazdaságét jócskán meghaladó bővülése. Miközben a nyolcvanas-kilencvenes évek fordulóján erőteljesen zsugorodott a magyar gazdaság, és a vállalatok jelentős része már csak a körbetartozások jóvoltából látszott fizetőképesnek, a bankok olyan kihelyezési politikát folytattak, mintha minden rendben lenne. Az MNB-utódbankok, valamint az OTP és a MKB épp úgy növekedtek, mintha változatlanul csak ők lennének a porondon, és a szinte a semmiből kinőtt, új bankok is látványos gyarapodást produkáltak a nyolcvanas évek végén, kilencvenes évek elején. A legjelentősebb egytucatnyi bank ebben a három évben 15 százalékkal növekedett gyorsabban, mint az a gazdaság, amelyben müködött. A banki mérlegekben kimutatott növekedési többlet azonban valójában már akkor is csak papíron létezett, köddé vált a nem fizető adósoknál.

\section{BANKKONSZOLIDÁCIÓ}

A banki válságok tünetei hamar megmutatkoztak, bár a bankvezetők a politikusokkal karöltve ideig-óráig leplezni próbálták. Sokáig azonban nem lehetett, mert az amerikai sajtó már 1991-ben hírül adta, hogy bizonyos magyar bankok a „technikai fizetésképtelenség” állapotában vannak. A tőkevesztés valójában be volt programozva. Helytállónak látszik Király Júlia hipotézise, amely szerint a bankok tőkevesztése egy olyan „válságspirál” folyamatába illeszthető, „amelyben a vállalati és banki tökevesztés kölcsönösen hatott egymásra, ahol a banki hitelkínálat szükülése a válságot mélyítő tényezővé válhat” (Király, 1995).

Ezt a „spirált” próbálta megtörni, illetve valamelyest enyhíteni a kormány hitel-, adós- és bankkonszolidációs programja. Bár a mentési akció közvetlenül elsősorban a bankokra irányult, hatóköre az egész gazdaságra kiterjedt. A kormányzati struccpolitika miatt megkésve elindított és sok anomáliával véghez vitt válságkezelés végül eredménnyel zárult: helyreállította a bankok hitelezőképességét, ami a gazdaság működésének elengedhetetlen feltétele.

Az első lépés, a csak jelképes segítségnek tekinthető garanciavállalás alig javított az érintett bankok helyzetén, sőt 1992 folyamán még súlyosbodtak is a gondok: az 
év végére a kétes és rossz hitelek már a hitelállomány ötödét is elérték. Az adósok pénzügyi helyzete drámaian romlott, és ezt a keleti piacok összeomlása mellett a csődtörvény is erősítette. A következő lépés az ún. hitelkonszolidáció volt, amelynek keretében 18 bank és 68 takarékszövetkezet százmilliárd forint értékü államkötvényt kapott cserébe csaknem kétezer adós rossz hiteléért. Mivel a kivásárlás általában 80 százalékos áron történt, a bankok olcsón megszabadulhattak behajthatatlannak látszó követeléseiktől, helyüket a piaci módon kamatozó, igaz, eladhatatlan, húszéves lejáratú államkötvények foglalták el. Egy év múltán az adósok egy részét is megsegítette a kormány: 1993 végén az állam a kormány által kijelölt állami nagyvállalatok (az ún. „piszkos tizenkettő”) hiteleit 90 százalékos áron megvásárolta a bankoktól, miután az állammal szembeni adósságuk egy részét elengedte, illetve átütemezte. A segélyakció kedvező hatásai azonban a legtöbb bank számára hamar elenyésztek. Igaz, az akció célja nem is a bankok terheinek könnyítése volt, hanem inkább az, hogy a bankok hitelezőként ne szólhassanak bele a politikailag fontos vállalatokkal kapcsolatos állami döntésekbe.

A bankoknak egyre több tartalékot kellett volna képezniük a rossz követelésekre, erre viszont nem volt pénzük, minthogy a megsegített 14 bank 1992-ben együttesen csaknem tízmilliárd forintos veszteséget produkált, 1993-ban pedig már a százmilliárdot is meghaladta a veszteségük. A fő baj azonban a bankok tőkehiánya volt, ami a rossz követelések kivásárlása ellenére is tovább nőtt, és 1993 végére a százmilliárd forintot is meghaladta. A magyar bankrendszer válságos helyzetének rendezésében szakértőként ténykedő Világbank hathatós tőkeinjekciót javasolt gyógykezelésül.

A kormány két lépésben (1993 végén és 1994 májusában), 148 milliárd forint értékű államkötvény felhasználásával akkora tőkeinjekciót adott a bankoknak, ami tőkemegfelelésüket 4 százalékra, a törvényben elöírt felére emelte. Készpénz hiányában állampapírokat használt a tőkeemelésekre. A tőkeemelés fejében a bankoknak szerződést kellett kötniük a Pénzügyminisztériummal, hogy részt vállalnak az ún. adóskonszolidációs eljárásban, amelynek keretében a vállalati reorganizációs programok alapján a bank elengedhette, átütemezhette vagy tulajdonná konvertálhatta az érintett vállalatok adósságainak egy részét. A szerződések arra is kötelezték a bankokat, hogy a költséggazdálkodás javítását, a szervezet észszerűsítését, a minősítési és hitelbírálati rendszerek javítását felölelő programot dolgozzanak ki, amelynek teljesítése esetén 1994 decemberében újabb tőkeemelést kaphattak. Ám végül csak a nagybankok kaptak annyit, amivel elérhették a törvényben előírt 8 százalékos tőkemegfelelést, a kisebbeket csak a 4 százalékos szintig tőkésítette fel az állam. A hitel-, az adós- és a bankkonszolidáció kétéves folyamatában összesen, 1994-es értéken számolva, 425 milliárd forintnyi konszolidációs államkötvényt használtak fel a kormányok a bankok és adósaik megsegítésére. Az összeg egyik feléből a bank adósokkal szembeni követeléseit 
vásárolta ki az állam, a másik felét pedig a bankok feltőkésítésére használta föl. Arra a kérdésre, hogy sok volt-e a nagy állami bankmentési akció mintegy négymilliárd dollárra rúgó, az éves GDP mintegy 10 százalékát kitevő végszámlája, többféle válasz adható. Ha azt nézzük, hogy ez az ország éves bruttó nemzeti termékének csaknem tizedét tette ki, akkor jelentősnek látszik a teher. Ha viszont azt nézzük, hogy az állami mentőakció nélkül összedőlt volna a bankrendszer és vele együtt az egész gazdaság, akkor megállapíthatjuk: a kisebbik rosszat választotta a kormány.

\section{NEHÉZ SZÜLÉS: DÖNTÉS A PRIVATIZÁCIÓRÓL}

A mentőakciókkal újra erős kormányzati befolyásolás alá került bankok nem sokáig élvezhették az állami emlő melegét: egy idő után elkerülhetetlenné vált az „elválasztás”, a bankprivatizáció. A nem túlságosan jó karban lévő magyar állam képtelen lett volna ennyi éhes csecsemőt táplálni, pláne, hogy már látszott: az állam ölében soha nem válnak alkalmassá az önálló életvezetésre. Mégsem volt könnyü a döntés a privatizáció módjáról, hiszen politikai és gazdasági érdekek erőterében kellett meghozni. A nyögvenyelősen megszületett, nagyléptékủ változásokat előidéző döntéseket végül az idő igazolta, bár sokakban komoly aggodalmakat váltott ki a külföldi tulajdonosok nagyarányú jelenléte a magyar bankrendszerben.

A külföldi tőke nemcsak a közép-kelet-európai térségben, hanem világviszonylatban is kirívó dominanciáját kettős kényszer szülte. Egyrészt a költségvetés növekvő hiánya elodázhatatlanná tette a privatizációt, de hiányoztak a tőkeerős hazai befektetők, akik képesek lettek volna a tőkeszegény bankok feltőkésítésére. Másrészt a leépülő, piacukat vesztő állami bankok helyét szép lassan elfoglalták a külföldi bankok újonnan alapított leányai. Ez épp úgy a privatizáció részének tekinthető, mint az állami bankok eladása, hiszen az új bankok megjelenése is növeli a bankrendszerben a magántulajdon arányát.

A bankprivatizációról szóló viták leglényegesebb elvi kérdéseiben, az állami, illetve a külföldi tulajdon részarányát illetően az 1991. novemberben elfogadott pénzintézeti törvény foglalt végül állást. Hosszas csatározás után a parlament megszavazta, hogy a banktulajdonosok számára felállított 25 százalékos limit (vagyis hogy egy tulajdonos közvetlen és közvetett tulajdonhányada - másik pénzintézet kivételével - nem haladhatja meg a 25 százalékot) általánosságban az államra is érvényes legyen. A törvény azonban lehetőséget nyújtott a privatizáció elhalasztására, mivel az államnak ötéves haladékot adott a tulajdoni hányad leszorítására. A másik gazdaságpolitikai dilemmát a külföldi befektetők megítélése jelentette. A „nemzeti tulajdon” védelme különösen a nagybankokkal kapcsolatban vetődött 
fel élesen. A fó érv az volt, hogy a külföldi kézbe kerülő nagybankok külföldi hitelfelvétellel keresztezhetik a monetáris politikát. A külföldi tulajdon ellenzői azt is felvetették, hogy a torz piaci viszonyok miatt (akkor még) igen jövedelmező bankszektorban keletkező nyereség a külföldi tulajdonosok révén kikerül az országból. Végül érvként szolgált azoknak az országoknak a példája, ahol a nemzetközi versenyképesség eléréséig nemzeti tulajdonban tartották a legnagyobb bankokat.

A törvényalkotók végül meglehetősen liberális megoldás mellett döntöttek. A 10 százalékos részarányt meghaladó külföldi tulajdonszerzést ugyan a törvény a kormány előzetes elvi hozzájárulásához kötötte, de az engedély megadásának - könnyen teljesíthető - elvi kritériumait is rögzítette. Az a javaslat pedig be sem került a törvénybe, hogy a bankszektor egészében 40 százalékban korlátozzák a külföldi tulajdon arányát.

Végül 1994 februárjában született meg a Boross-kormány bankprivatizációs stratégiája, amely kimondta, hogy mindenekelőtt szakmai stratégiai befektetőket kell keresni. Azonban már csak egyetlen bank, az állami tőkejuttatásra nem szoruló Magyar Külkereskedelmi Bank privatizációjára kerülhetett pont a Boross-kormány fennállása alatt. A többi bank esetében a késlekedésben a bankkonszolidáció elhúzódása, a bankok vártnál súlyosabb tőkepozíciója is szerepet játszott.

Az 1994 nyarán megalakult Horn-kormány azt ígérte, hogy a bankkonszolidáció az előző kormány által már megígért tőkejuttatásokkal befejeződik. A privatizációs törvény mégsem foglalkozott a bankokkal, csupán annyit állapított meg, hogy a bankprivatizáció módjáról, a bankok felkészítéséről, a stratégiai befektetők kiválasztásáról, az eladás módjáról a jövőben a kormány dönt. Jelzésértékű volt ugyanakkor, hogy a törvényjavaslat szerint a tartósan állami tulajdonban maradó társaságok között csak két pénzintézet, az OTP és az MFB szerepelt, és ezekben is csak 25 százalék plusz egy szavazatnyi hányadot írt elő a törvény

Az elvi lehetőség tehát megnyílt a bankok eladására. A probléma egyre inkább gyakorlati útra terelődött: hogyan lehet komoly szándékú szakmai befektetőt találni a rendbetételük után sem kellően átlátható, nehezen felbecsülhető kockázatú követelésekkel rendelkező bankokhoz. A feljavított bankok eladása ezért csaknem minden esetben pótlólagos állami segítségnyújtást igényelt. A BB a sikeres privatizáció érdekében titkos kormánydöntés alapján 12 milliárd forint tőketartalékot kapott a kormánytól, és az eladáshoz a bank vevőjének adott 8 milliárd forintos eszköz-visszavásárlási garancia társult. Két tőkehiányos bank, a Mezőbank és az Agrobank fúzióját az állam 9 milliárd forint tőkejuttatással segítette 1995-ben. 1996 tavaszán az állam garanciát vállal az MHB rossz portfólióját kezelő Risk Kft. 11 milliárd forint értékű kötvénykibocsátására, az OKHB „kistafírozása” érdekében pedig az ÁPV Rt. és az MFB vállalt portfóliócseréket 1997-ben. 
A nem szűnő támogatási igények világossá tették: ameddig nem kerül sor a bankok privatizálására, remény sincs az állami segítségfolyam megállítására. Ez a felismerés is hozzájárult ahhoz, hogy 1994 végén a Horn-kormány a privatizáció minél gyorsabb véghezvitelét tűzte ki célul. Az ideológiai-szakmai viták azonban újból felélénkültek. A Pénzügyminisztérium a mielőbbi, ezért a szakmai-stratégiai befektetők előtt utat nyitó privatizációt szorgalmazta. Ezzel szemben az Állami Vagyonkezelő Rt. 1994. őszi belső tanulmánya megállapította: „Stratégiai befektetők nagyrészt reménytelen és részben parciális érdekek által motivált kutatása helyett (...) nyilvános forgalomba hozatal javasolható. A privatizáció során kívánatos a bel- és külföldi portfólió-befektetők (a külföldi nyugdíjalapok, intézményes befektetők, belföldi társadalombiztosítás, biztosító társaságok, önkormányzatok stb.) részesedése.” Az Országgyủlés által 1995-ben elfogadott privatizációs stratégia végül a PM álláspontját tükrözte, minthogy leszögezte: „a bankprivatizáció során elsősorban szakmai, stratégiai befektetők bevonására van szükség”. ${ }^{2}$

Két kivétel volt ez alól. Az egyik az OTP, amelynek vezetője elkerülhette a külföldi pénzintézet(ek) megjelenését a bankjában, és amellett, hogy megőrizhette elnök-vezérigazgatói székét, a szórt tulajdon kialakítása miatt a befolyása is megmaradt a stratégiai döntésekben. ${ }^{3}$ Míg a tőzsdére is bevezetett OTP esetében végül nem igazolódtak be a kialakult tulajdonosi szerkezet miatti aggodalmak, a Postabank története megerősítette azokat. A már korábban részben külföldi befektetők kezébe került Postabankot is kellő ellenőrzést nélkülöző, szórt tulajdonosi struktúra jellemezte, még megroppant tőkehelyzete ellenére is elkerülhette a szigorúbb kontrollt gyakorló tulajdonosok megjelenését, így vezetője szabad utat kapott a végzetesnek bizonyult ámokfutásához (Várhegyi, 2002). Valódi privatizálására már csak a kényszerű újraállamosítását követően, 2002-ben került sor (Király, 2005).

\section{ELADÁSOK FUTÓSZALAGON}

A magyar bankszektor legtöbb tagjának privatizációja végül a döntést megelőző vajúdásnál gyorsabban zajlott le. Az első jelentős akció az MKB részleges eladása volt 1994 nyarán, amit részben a bank megfelelő állapota tett lehetővé, részben az, hogy a bank politikai szempontból kevésbé számított kényesnek, mint a lakossági megtakarításokat összpontosító OTP vagy a nagyipar és az agrárgazdaság döntő részét finanszírozó MNB-utódbankok. Első lépésben a részvények kisebb hányadát adták el úgy, hogy a szakmai befektető Bayerische Landesbank (BLB) mellett az Európai Beruházási és Újjáépítési Bank (EBRD) is szerepet kapott a

2 Idézi Mihályi (1997), 65. o.

3 Az OTP „különutas” privatizációjának tárgyalása szétfeszítené e cikk kereteit. L. bővebben VÁRHEGYI (2OO2), 52-58. o. 
bank irányításában, ami a BLB számára is biztonságot nyújtott, mert így nem egyedül kellett viselnie az ismeretlen bankban rejlő kockázatokat. A BLB ekkor 25,01 százalékos tulajdonhányadot szerzett, ami éppen arra volt elég, hogy nélküle ne lehessen stratégiai döntést hozni. Ugyanekkora hányadot tartott meg magának az állami tulajdonos, az EBRD pedig 16,7 százalékot szerzett, ezeket két évvel később, a privatizáció második fordulójában - opciójával élve - kivásárolta a bajor tulajdonos.

Az 1995-ben felkínált bankok közül csak a Budapest Bankot sikerült részlegesen privatizálni, és azt is csak pótlólagos állami rásegítéssel: 12 milliárd forint tartaléktőkét kapott a kormánytól azzal a feltétellel, hogy a privatizáció kudarca esetén ezt az összeget az év végén vissza kell fizetni. Mivel a hozomány ellenére két kérő is visszalépett vásárlási szándékától, az önmagát szűk időkorlátok közé záró eladó kénytelen volt elfogadni az egyetlen olyan ajánlatot, amellyel a tőkekölcsön lejárata előtt lebonyolítható volt az adásvétel. Így végül 1995 decemberében az EBRD és az amerikai General Electric Capital (GEC) vásárolta meg névértéken a bank részvényeinek 60 százalékát kitevő 12 milliárd forintos pakettet. Az akció nyomán az EBRD 32,4, a GEC 27,4 százalékos részesedést szerzett a bankból, valamint 2001-ig szóló opciót a fennmaradt állami részvénypakett megvételére.

A hitel- és bankkonszolidáció két „főszereplője” közül elsőként a Magyar Hitel Bank privatizációja zárult le. Az állam előzőleg még segített megtisztítani a bankot a konszolidáció után megmaradt rossz hiteleitől, az MNB pedig megszabadította a kevéssé likvid konszolidációs kötvények zömétől. A válságmenedzselést vállaló, új vezetés is igyekezett vonzóvá tenni a menyasszonyt: karcsúsította a kiterjedt fiókhálózatot, leépítette a létszámot. Az erőfeszítések gyümölcse 1996 őszére érett be, amikor a nyugati szakmai befektetők igen nagy érdeklődést mutattak az eladósorba került bank iránt. A legjobb ajánlatot a Magyarországon már leánybankkal rendelkező holland ABN Amro Bank tette: a 89 százalékos részvénypakettért 89 millió dollárt ígért és további 137 millió dollár tőkeemelést. A vétel után egy évvel az MHB összeolvadt a tulajdonos itteni leánybankjával, és attól kezdve ABN Amro (Magyar) Bank néven működött a magyar piacon. Nem sokáig: három év vegetálás és húszmilliárd forint veszteség elszenvedése után öszszeolvadt az időközben belga tulajdonba került K\&H-val.

Az MHB eladásával megtört a jég: egyre több magyar bank iránt kezdtek érdeklődni a külföldi pénzintézetek. A szakmai befektetők számára ez volt az utolsó lehetőség arra, hogy kialakított ügyfélkör felvásárlásával nyerjenek piacot. Elsőként a takarékszövetkezeti kapcsolatai miatt fontossá vált Takarékbank kelt el 1997 tavaszán. A jelentős állami segítség ellenére tőkeleszállításra kényszerült bank jegyzett tőkéjének 61 százalékát vásárolta meg a német DG Bank és a Hungária Biztosító alkotta konzorcium, ám a szükségessé vált tőkeemelést követően a DG Bank a bank 90 százalékát szerezte meg, míg a takarékszövet- 
kezeteknek és a Hungáriának 5-5 százalékos tulajdonrész jutott. Gyorsan zajlott le az Agrobankot bekebelező, széles fiókhálózattal és ügyfélkörrel rendelkező Mezőbank eladása is. Részvényeinek 84 százalékát az osztrák Erste Bank vette meg, és tőkeemelést is vállalt. A Mezőbank új tulajdonosa Ausztria akkori második legnagyobb bankja lett.

A széleskörű ügyfélkapcsolattal, kiterjedt fiókhálózattal jó piaci pozíciót szerzett K\&H privatizációja csak 1997 öszén történt meg. A tőkevesztés miatt a korábbi ötödére, mindössze 10,4 milliárd forintra zsugorodott tőke 9,7 százalékát a belga Kredietbank és az Irish Life biztosító vette meg, de a vásárlásba az EBRD is beszállt. A tőkeemelések eredményeként a belga-ír konzorcium tulajdona 57 százalékra, az EBRD-é pedig 17 százalékra emelkedett. Az állami tulajdon végül az ezredfordulóra tűnt el a bankból azt követően, hogy a K\&H tízmilliárd forintos veszteséget szenvedett el 1999-ben, és ezzel tőkebázisa is megroggyant. Miután az állami tulajdonos azzal is fenyegetőzött, hogy tulajdonrészét eladja a konkurens OTP-nek, a belga tulajdonos magára vállalta a K\&H tőkevesztésének ódiumát, és tízmilliárdos tőkeinjekciót adott a banknak.

1997 végére tehát nagyjából befejeződött a magyar bankprivatizáció. Időközben az MNB már a kilencvenes évek első felében megvált a Citibankban és a Unicbankban lévő érdekeltségeitől, 1997-ben pedig a CIB-től is megvált. A kormányzati célokat szolgáló állami bankok (MFB, Eximbank, Földhitel- és Jelzálogbank) mellett csak néhány kisbank maradt pártában (a Konzumbank és a Corvinbank, amelyeket később, összeolvasztva az MFB védőernyője alá helyeztek). 1998-ban a csődközeli helyzetbe került Postabank állami megmentése miatt még egy intézménnyel szaporodott az állami bankok kicsiny tábora. Ezzel együtt is eredményes volt a bankszektor „államtalanítása”: az állami tulajdon aránya 20 százalék alá csökkent, az állami bankok piaci súlya pedig 10 százalék alá esett vissza.

A külföldi befektetők bevonásával lezajlott privatizációk és az újonnan alapított bankok együttesen szokatlan tulajdonosi szerkezetet hoztak létre a magyar bankrendszerben. Az ezredfordulón müködő 42 hitelintézet közül 32 többségi, egy pedig kisebbségi külföldi tulajdonban volt. A többségi külföldi tulajdonú bankok részesedése a bankszektor tőkéjében és eszközeiben is elérte a kétharmados arányt, és ez később tovább nőtt, amikor a 23 százalékos piaci súlyú OTP-ben is többségbe került a külföldi tulajdon. Ez a helyzet 2010 után változott meg, amikor az Orbán-kormány célul tűzte ki, hogy a bankszektor legalább felerészben „nemzeti” tulajdonba kerüljön. 


\section{VÁGTA ÉS VERSENY}

Az ezredfordulót követően, egészen a 2008-as hitelválság eszkalálódásáig a nagyrészt privatizált, kellő tőkével ellátott és szolgáltatásaiban modernizált magyar bankrendszer a fénykorát élte. Ennek előnyeit az ügyfelek is élvezhették: bár a bankolás költségei magasabbak voltak, mint a nyugati országokban, az elérhető termékek köre és a kiszolgálás minősége már megközelítette az ottani szintet. Csak példaként: miközben a magyar fejlődés átlépett a nehézkes csekkrendszeren, 2001-ben már csaknem ötmillió bankkártyával rendelkeztek az ügyfelek, és ezeket két és félezer ATM-nél, illetve POS-terminálnál használhatták. A korszerü termékek mind szélesebb skálája mellett új, gyakran látogatott helyeken (pl. üzletközpontokban megnyitott) fiókokkal is igyekeztek a bankok ügyfeleket toborozni és magukhoz láncolni.

A változás a bankok között feléledő versengésben is megmutatkozott. A kilencvenes évek elején az újonnan alapított, rossz örökségektől mentes bankok a puszta jelenlétükből is profitálhattak, nem kellett nagy erőfeszítéseket tenniük azért, hogy elhódítsák az ügyfeleket az alacsony színvonalú szolgáltatásokat nyújtó állami bankoktól. A kilencvenes évek közepétől azonban ez a stratégia már nem volt kifizetődő: bővült a jó szakmai hátteret kiépítő bankok köre, miközben az állami segítséggel megtisztított és privatizált bankok is új erőre kaptak. Az ezredfordulóra szinte élet-halál harc terepévé vált a magyar bankpiac: a „vagy te zabálsz föl valakit, vagy téged esznek meg” farkastörvény vált uralkodóvá.

A bankprivatizációt követően már kevés zöldmezős bankalapítás történt, ami elsősorban a piac telítődésével és a verseny erősödésével magyarázható, de az is szerepet játszhatott ebben, hogy külföldön a fejlettebb bankrendszerekben gőzerővel beindultak a fúziós és felvásárlási folyamatok. A stratégiaváltás abban is megmutatkozik, hogy az évtized második felében a magyar piacra belépő külföldi bankok már elsősorban a piaci réseket célozták meg: ekkor alapították az „autós bankokat" (Opel, Porsche), valamint a fogyasztási hitelezésre (Cetelem), illetve a lakásfinanszírozásra szakosodott hitelintézeteket. Az évtized végén kilépésekre is sor került (ING, Nomura, Citibank), bár ezek általában nem jelentették a magyar pénzügyi piacról való távozást, inkább csak bizonyos üzletágak eladását vagy tevékenységek feladását.

A vállalati piac telítődése és a verseny kiéleződése miatt az ezredfordulóhoz közeledve megindult a küzdelem a lakossági hitelezésben is, és egyre több bank aktivizálódott ezen a piacon. A külföldi szakmai hátterük miatt fejlett banktechnológiával működő versenytársak megjelenése a hagyományos lakossági bankokat is szolgáltatásaik fejlesztésére késztette. A verseny hatására ugrásszerű fejlődés ment végbe a folyószámla- és kártyaszolgáltatásokban, a fogyasztói hitelezésben, valamint a fiókhálózat kiépítésében. A lakáshitelezésben az ezredforduló hozott 
áttörést, amit a növekedésbe lendült a gazdaság, az ingatlanpiac stabilizálódása mellett a kormány mind kedvezményesebbé váló kamattámogatási rendszere is ösztökélt.

A bankok között felerősödő verseny azonban nem volt mentes a torzulásoktól. A versenyt eleve korlátozta a bankpiac struktúrája, amely magán viselte az örökölt egyenlőtlenségeket, ami - az OTP különleges helyzetéből fakadó erőfölénye miatt $^{4}$ - fóleg a lakossági piacot jellemezte. A magyar bankpiac versenyviszonyait az ezredfordulón vizsgáló elemzések többféle torzulásra is rámutattak.5 Többek között arra, hogy a magyar bankrendszerben a nemzetközi összevetésben viszonylag gyenge hatékonysághoz magas jövedelmezőség párosult, ami megerősítette annak a gyanúját, hogy a piaci szerkezet kedvező változásai ellenére korlátozott maradt a verseny. A modellbecslések közepes fokú, az idő függvényében kissé erősödő versenyt mutattak 1995-2002 között. A lakossági hitelpiacon olyan mértékben voltak rugalmatlanok a kamatok a pénzpiaci kamatokat tekintve, ami lehetőséget nyújthatott oligopolisztikus járadék érvényesítésére, sőt, erre a lakossági betétek árazása is teret engedett.

A 2006 őszén felállt Lakossági Pénzügyi Szolgáltatásokat Vizsgáló Szakértői Bizottság szerint „a hazai lakossági bankpiacokon több probléma is gátolja a működőképes verseny fokának növelését. Ezek a problémák a piaci szerkezettel, a piac transzparenciájával, a fogyasztóvédelemmel, illetve a pénzügyi szektor közvetítő szerepének korlátozott voltával kapcsolatosak" (Bankbizottság, 2006). A jelentés azt is megállapította, hogy az OTP dominanciája a lakossági piacon lehetőséget adott a „vezetőkövető” modell érvényesülésére, amely a piacvezető bank számára biztosította a magas profitszint fenntartását és a modernizációját, miközben a versenytársak számára a nagy költséggel járó terjeszkedést fedező nyereséget tett lehetővé.

Az árakon alapuló verseny korlátozottsága azonban nem jelentette a verseny teljes hiányát, mivel a nem áralapú verseny érzékelhetően nőtt a kétezres években. Ez kezdetben az úgynevezett költségalapú versenyben jelentkezett, és elsősorban az értékesítési csatornák bővítésében öltött testet: ennek jegyében nőtt jelentősen a bankok hálózata és létszáma, valamint marketingtevékenysége. A hálózatfejlesztéssel - a korábban főként a vállalati piacokon aktív - bankok előbb a lakossági hitelpiacot, később a betétek piacát vették célba. Az évtized közepén, amikor a forintalapú jelzáloghitelezés a lakáshitelek kamattámogatásainak viszszanyesése miatt kifulladt, mindinkább teret nyert az úgynevezett kockázatalapú verseny, kezdetben a devizahitelezéssel, később az ügyfél- és hitelezési kockázatok növelésével (a jövedelemvizsgálat elhagyása, a hitel/fedezet arány növelése, a

4 A piacvezető bank sajátos helyzetéről lásd bővebben VÁRHEGYI (2011).

5 Móré-Nagy (2004); VÁrhegyi (2003). 
növekvő törlesztés/jövedelem arány), vagyis a prudenciális szempontok fellazításával. Mindez mérsékelte a piacvezető OTP jelentős fölényét a lakossági piacon, különösen a betétek és a jelzáloghitelek esetében csökkent a koncentráció (BanaiKirály-Nagy, 2010).

\section{VÁLSÁG ÉS VÁLSÁGKEZELÉS}

A magyar bankszektor aranykorának a 2008-as hitelválság vetett véget. Nem csupán maga a válság idézte elő a banki aktivitás hanyatlását, hanem a magyar kormány sajátos „válságkezelése” is, amely különféle sarcokkal még jobban beszúkítette a bankok mozgásterét és a bankolás lehetőségeit.

Magyarország annak ellenére került a nemzetközi hitelválság által erősen sújtott országok táborába, hogy nemcsak a krízis kialakulásában, de még annak tovagyürüzésében sem volt szerepe. A magyar bankok nem vagy csak kis mennyiségben vásároltak és forgalmaztak „mérgezett” értékpapírokat, ezért nem járultak hozzá a likviditási válság eszkalációjához. Mégis, a gazdaság és benne a bankok sebezhetősége miatt a hitelválság különös erővel érintette Magyarországot - és annak bankszektorát is. ${ }^{6}$ A sérülékenység jórészt a 2001-2006 között folytatott fogyasztásösztönző gazdaságpolitikára vezethető vissza, amely amellett, hogy a pénzügyi egyensúlyok megbomlásához vezetett, ösztökélte a bankok túlfütött hitelezési expanzióját, amely 150 százalékra emelte az átlagos hitel/betét arányt és megnövelte a kockázatokat. A kihelyezésekért folyó versenyben a bankok egyre kevésbé voltak tekintettel az adósok hitelképességére, miközben folyamatosan növelték a hitel/fedezet arányt és a hitelek futamidejét.

Bár a magyar bankok túlnyomó többsége mögött tulajdonosként hosszú távon elkötelezett nyugat-európai anyaintézetek álltak, a pénzügyi krízis őket is nehéz helyzetbe hozta. A közép-kelet-európai régióban legaktívabb bankok együttes fellépése, az anyaországok kormányai, felügyeletei és az EKB vezetői körében a távlatosabb érdekek előtérbe kerülése, továbbá az érintett országok jegybankjainak a devizalikviditásért tett segítỏ lépései végül enyhítették a válságnak a térség bankjait érintő hatását. A külföldi anyabankok jelentős szerepet vállaltak a likviditási válság hatásainak tompításában: növelték leánybankjaik finanszírozását, és ahol szükségessé vált, tőkeemeléssel, illetve a profit visszaforgatásával teremtették elő a biztonságos működéshez szükséges tőkeszintet (Banai-Király-Nagy, 2010).

6 Lásd föként KirÁLy (2008); KirÁLY-NAGY-SZABó (2008); SURÁNYI (2008); VÁRHEGYI (2008); FENYö-VÁRHEGYi (2010). 
A válság alkalmazkodásra kényszerítette a bankokat, ami elsősorban a magas hitel/betét arány csökkentésében, a hitelezés visszafogásában és a betétgyüjtési verseny erősödésében öltött testet. A bankok szigorították a hitelezés feltételeit (csökkentették a hitel/fedezet arányt, megnövelték a sajáterö-követelményt, a hitelképességi vizsgálat során újból általánossá tették a jövedelemvizsgálatot), egyes üzletágakat - elsősorban az ingatlanprojekt-finanszírozást - pedig a hitelezés leállításával gyakorlatilag befagyasztottak. Esetenként felmondták a már megítélt hiteleket, a szerződéseket egyoldalúan, az ügyfél számára hátrányosan módosították, ha ilyenekre a jogszabályok, illetve jogi kiskapuk lehetőséget adtak. Az egyoldalú szerződésmódosítások elharapózó gyakorlata a szabályozók és a közvélemény körében is egyre nagyobb ellenérzéseket szült 2009 tavaszán-nyarán, ami felgyorsította a bankszektor önszabályozó eszközeként müködő magatartási kódex létrehozásának évek óta húzódó folyamatát.

A válság önerősítő folyamatot indított be: a hitelezés akadozása és feltételeinek szigorodása rontotta az adósok helyzetét, és tovább mélyítette a recessziót, miközben a gazdaság hanyatlása csökkentette a bankok hitelezői képességét és hajlandóságát, ami tovább fokozta a gazdaság összehúzódását. Erre tett még rá egy lapáttal a 2010ben hatalomra került kormány rövidlátó, költségvetési mozgásterét elsősorban a bankokat sújtó különadóval és más elvonásokkal növelő politikája. A válság indokával 2010-ben bevezetett magyar bankadóval szemben több probléma is felvethető volt. Az adó nemzetközi összehasonlításban kirívó és a magyar bankok adottságaihoz képest is eltúlzott mértéke, valamint a kivetés módja (az adókivetés alapja a 2009. év mérlegföösszeg) sok pénzintézetnél tőkevesztést idézett elő. A már lezárult év tevékenységének utólagos megadóztatása egyúttal a jogbiztonságot is sértette, miközben a versenysemlegesség elve is sérült amiatt, hogy különböző méretű pénzintézetekre eltérő százalékos terhet rótt. Az adó indoka és a felhasználás módja között is ellentmondás feszült, minthogy az adó a költségvetésbe, nem pedig egy későbbi válsághelyzet kezelését szolgáló alapba folyt be?

A 2008 őszén kirobbant hitelválság, majd 2010 nyarától a svájci frank erősödésének a hatására leértékelődő forint jelentősen megnövelte a korábban elterjedt deviza- (zömmel frank-) alapú hitelek törlesztőrészleteit, és ez rövid idő alatt súlyos társadalmi problémává szélesedett. A probléma súlyához képest ugyanis Magyarországon későn vezették be a szabályozási intézkedéseket, és első lépésben az is csak a japánjen-alapú hitelezést állította le, miközben a frankhitelek még a hitelválság kirobbanását követő pár hónapban is tovább bővültek. A kormány csak 2009 végén hozott a devizahitelezést korlátozó rendeletet (amikor már a válság hatására gyakorlatilag mindenféle hitelezés leállt), a devizaalapú jelzáloghitelezést pedig 2010 augusztusában tiltották be.

7 Az intézkedések hatásairól lásd bővebben: VÁRHEGYI (2011). 
A devizaadósok megsegítését célzó intézkedések viszont jelentős terheket hárítottak a bankokra, amelyeket már a túlméretezett bankadó is sújtott. A 2011. szeptember végén hatályba lépett végtörlesztési törvény, amely arra kötelezte a bankokat, hogy 180 forintos svájcifrank- és 250 forintos euróárfolyamon fogadják el az egy összegben visszafizetett devizahitel-tartozásokat, a piaci árfolyam ezt meghaladó részét pedig veszteségként számolják el. Mivel a végtörlesztés lehetöségével csak a tartalékokkal rendelkező, fizetőképes ügyfelek tudtak élni, a bankok fennmaradó lakossági hitelportfóliójának minősége, s így jövedelemtermelő képessége tovább romlott. Mintegy ezermilliárd forintnyi terhet rótt a bankokra a 2014 júliusában életbe lépett „elszámolási” törvény is, amely visszafizettette velük az egyoldalú szerződésmódosítással kieszközölt törlesztési többleteket. A dolog szépséghibája, hogy a törvény szerint ezeket a 2004. májusi uniós csatlakozásig visszamenően kellett visszatéríteniük, holott a szerződések módosítását csak a 2010-töl hatályos hitelintézeti törvényben szabályozták. A devizahitelek problémáját végül a forintosításról szóló 2015. évi CXLV. törvény kezelte hatásosan, amelynek eredményeként 3500 milliárd forintnyi lakossági devizahitel tünt el a piacról. A magyar bankrendszer ért kettős sokk, a válság és a sajátos „válságkezelés” jelentősen visszavetette a szektor teljesítményét. A jövedelmezőség 2010-re gyakorlatilag lenullázódott, ami a tulajdonosi tőkepótlások ellenére is a hitelezési képesség romlásával járt együtt. Lezárult a 2000-es évek felívelő szakasza, az „aranykor”, amely nemcsak a banki jövedelmezőségekben mutatkozott meg, hanem a magyar bankélet minden vonatkozásában jelentős fejlődést hozott, miközben a fejlett európai térséghez tartó konvergencia útján is nagy elörelépést jelentett. A magyar bankok anyabankjai az itteni adottságokhoz illeszkedő „üzemmódba” váltottak át, amelyet a Bankszövetség akkori elnöke így jellemzett: „maradnak, kivárnak, de befagyasztják tevékenységüket, azaz zombivá alakítják át itteni leányvállalataikat" (Felcsuti, 2011).

\section{A „NEMZETIESÍTÉS” JEGYÉBEN}

A banki különadó mellett a bankok többségét a mind jobban kiterjedő gazdasági válság nyomán leértékelődő hitelfedezetek (főként kereskedelmi ingatlanok) és az ügyfelek fizetési gondjai is nehéz helyzetbe hozták. A korábbi évek hitelezési „vágtája” során vállalt, gyakran túlméretezett kockázatok (projektfinanszírozás, devizaalapú hitelezés) 2010-től erőteljes mérlegleépítésre kényszerítette őket. A válságos helyzet kezelését a bankok terheit megnövelő kormányzati intézkedések is nehezítették, ami további tőkepótlásokat tett szükségessé. A válság hat éve alatt a külföldi tulajdonosok több mint 1500 Mrd Ft értékü tőkeemelésekkel siettek a 
leánybankok veszteségeinek fedezésére. Ez hozzávetőleg a válság alatti éves GDP 5-6 százaléka volt, ami nélkül a gazdaság összeomolhatott volna.

Mindeközben a magyar kormány a bankszektor „nemzetiesítése” jelszavával igyekezett átformálni a magyar bankrendszert és a piaci pozíciókat. A 2010 tavaszán meghirdetett cél a „nemzeti” bankok részarányának 50 százalékra emelése volt, ami magában foglalja a piac negyedét uraló, többségi külföldi tulajdonban lévő OTP Bankot is, minthogy ezt épp úgy belföldről irányítják, mint a hazai tulajdonban lévőket. Ám nem csupán ebben mutatkozott meg az átrendeződés. A kormány egyes pénzintézeteket a politikai hatalomhoz közel álló új tulajdonosok kezébe juttatott, és helyzetüket különféle kormányzati és jegybanki segítséggel próbálta javítania. Eközben a válság miatt amúgy is összehúzódó külföldi leánybankokat - a főként őket sújtó elvonásokkal ${ }^{8}$ - még inkább a tevékenységük visszafogására késztette, és így a piacról való kiszorításukkal párhuzamosan teret nyerhettek a kormány által preferált, „nemzeti” tulajdonú pénzintézetek.

A „nemzetiesítés” jegyében a magyar állam megvásárolta bajor tulajdonosától az MKB Bankot, és a frissen elfogadott szanálási törvénnyel a bank az MNB kezébe került, hogy kitisztítása után újraprivatizálás útján megint eladják. Ez 2016-ban lezajlott, bár a bank tulajdonosi szerkezete azóta is folyamatosan változik, jelen állás szerint a tulajdon meghatározó része a kormányfőhöz közel álló gazdasági körökhöz került. A tervek szerint a tulajdonosok tőzsdére vinnék a bankot, de ennek realitása kérdéses. A Budapest Bankot 2015-ben vette meg a magyar kormányt képviselö MFB amerikai tulajdonosától, a GE-től azzal az ígérettel, hogy legkésőbb három év múlva újból magánkézbe adja. Bár a határidő már lejárt, a bank sorsa még nem dőlt el.

Szintén a nemzeti tulajdoni arány növelése érdekében egyezett meg az állam az Erste Bank tulajdonosával, hogy tulajdonrészt vásárol a bankból, elfogadva annak feltételét, hogy ugyanekkora, 15\%-os részesedést szerez az EBRD is a bankban. A 2016-ban lezajlott tranzakciónak azért is van jelentősége, mert a tulajdonszerzéssel párhuzamosan a kormány kötelezettséget vállalt arra, hogy tartózkodik a bankszektort hátrányosan érintő szabályozástól. Ezen időszak alatt a „nemzeti” tulajdont erősítette egyes, a politikai hatalomhoz közel álló kisbankok állami tőkejuttatása, valamint a növekedésükhöz nyújtott, közvetett jegybanki segítség is. Bár nem a „nemzetiesítés” vezérelte a takarékszövetkezeti szektor tulajdonviszonyainak gyökeres átalakítását (hiszen azok már eleve hazaiak voltak), de az tette lehetővé, hogy 2012-ben az MFB kivásárolta a takarékszövetkezetek ernyőbankjában tulajdonos német DZ Bankot. A takarékszövetkezetek régóta kívánatos, szo-

8 A mérlegföösszeg arányában megállapított bankadó jóval nagyobb százalékos elvonást állapított meg a nagyobb méretü, többnyire külföldi kézben lévő pénzintézetekre, mint a zömmel magyar tulajdonú kicsikre. 
rosabb integrációját központilag oldották meg, amelyet a kormány 136 milliárd forintos tőkejuttatása erősített meg. Ennek azonban komoly ára volt. A tulajdonviszonyok erőszakos átrendezése révén a szövetkezeti tagság többsége elveszítette-elveszíti befolyását, a szektor egy olyan országos hálózattal rendelkező „kereskedelmi bankká” válik, amelyet szintén a kormányhoz közeli gazdasági erők irányítanak, s amely vélhetően versenytársa kívánna lenni a legnagyobb magyar bankcsoportnak.

A fenti tranzakciók hatására hét év alatt az ún. nemzeti irányítású hitelintézetek piaci aktivitás (mérlegföösszeg) szerinti részesedése 13,5 százalékponttal, 55,7\%-ra emelkedett. ${ }^{9}$ A bankrendszer jövőbeni stabilitása szempontjából két fontos kérdés merül fel ezzel kapcsolatban. Az egyik: az újonnan „nemzetiesített” hitelintézetek kellően tőkeerős tulajdonosokkal rendelkeznek-e ahhoz, hogy szükség esetén helyt tudjanak állni? A másik: a politikai hatalommal való szoros összefonódás milyen hatással van a prudens bankműködésre, mennyire erősödött meg az erkölcsi kockázat?

\section{ZÁRSZÓ}

A hosszú évek viszontagságai után mára magához tért a magyar bankrendszer. Ebben egyaránt szerepet játszik a gazdasági környezet javulása, a szektorra irányuló szabályozási nyomás enyhülése (csökkent a bankadó és a tranzakciós illeték), valamint a banki erőfeszítések (pl. költségcsökkentés) hatása. A bankok többsége újra jelentős profitot termel, igaz, jelentős részben a korábban megképzett tartalékok felszabadítása miatt. A rossz portfóliók kitisztítása nagyrészt lezárult - a lakossági fronton még vannak teendők -, újra megindult a vállalati és lakossági hitelezés, amelyet a jegybank és az állam is ösztönöz. Az ingatlanárak emelkedése újra vonzóvá tette a projekthiteleket, és a lakossági fogyasztás növekedése, valamint a korábbi adósságok „eltűnése” is ösztönzi a hitelezést. Kérdés azoban, hogy a megint gyorsan bővülő hitelek a fenntartható gazdasági növekedést támogatják-e, vagy a kockázatokat növelik meg újra.

Az emberöltőnyi idő mérlegét megvonva mindenesetre megállapíthatjuk, hogy a kedvezőtlen örökségek és időközben felbukkant nehézségek ellenére jelentős fejlődés ment végbe, és nemcsak mennyiségi, hanem minőségi értelemben is. Mégsem könnyű egyértelmüen eldönteni, hogy a zo éve újjászületett magyar bankrendszer képes-e érett „felnőttként” felelős módon, döntéseinek következményeit is mérlegelve „viselkedni”. Ám ez korántsem magyar sajátosság: a 2008-ban kirobbant hitelválság jól demonstrálta, hogy az éltesebb bankszektorokban is könnyen elural-

9 Forrás: MNB, https://www.mnb.hu/felugyelet/idosorok/i-penz-es-hitelpiaci-szervezetek/ hitelintezetek 
kodhat a felelőtlenség, ha a külső környezet ebben nem gátolja. Mindez azzal a tanulsággal szolgál, hogy miként az emberek életében, úgy a bankrendszerekében sem lehet elégedetten hátradőlni és kijelenteni: most már elég bölcsek vagyunk ahhoz, hogy ne hibázzunk.

\section{HIVATKOZÁSOK}

BANAi ÁdÁM - KIRÁly Júlia - NAGY MÁRTON (2010): Az aranykor vége Magyarországon. „Külföldi” és „lokális” bankok - válság előtt és válság után. Közgazdasági Szemle, LVII. évf. 2. sz.

Bankbizottság (2006): Javaslatok a lakossági bankszolgáltatások problémáinak kezelésére. Lakossági Pénzügyi Szolgáltatásokat Vizsgáló Szakértői Bizottság, 2003. dec.

Felcsuti Péter (2011): Zombi bankok Magyarországon. Portfolio.hu, 2011. szeptember 30.

Fenyő György - VÁrhegyi Éva (2010): A válság hatása a bankszektorra. Külgazdaság, 54. évf. 3-4. sz.

KIRÁLY JÚLIA (1995): Válságspirál, avagy a magyar bankok tőkevesztésének értelmezése. Közgazdasági Szemle, XLII. évf. 9. sz.

KirÁly Júlia (2005): Egy bank, amely közel állt Önhöz. A Postabank privatizációjának története, 2002-2003. Budapest, ÁPV Rt.

KirÁly Júlia (2008): Likviditás válságban (Lehman előtt - Lehman után). Hitelintézeti Szemle, 7. évf. 6. sz.

KIRÁly JÚLIA - NAGY MÁRTON (2008): Jelzálogpiacok válságban: kockázatalapú verseny és tanulságok. Hitelintézeti Szemle, 7. évf. 5. sz.

Király Júlia - NAgy Márton - Szabó E. Viktor (2008): Egy különleges eseménysorozat elemzése - a másodrendű jelzálogpiaci válság és (hazai) következményei. Közgazdasági Szemle, XLV. évf. 7-8. sz.

Kornai János (1993): Transzformációs visszaesés. Közgazdasági Szemle, XL. évf. 7-8. sz.

Mihályi PÉter (1997): A bankprivatizáció tanulságai. Külgazdaság, 41. évf. 10. sz.

Móré Csaba - NAgy Márton (2004): Verseny a magyar bankpiacon, MNB Füzetek, 2004/9.

SurÁNyi György (2008): A pénzügyi válság mechanizmusa a fejlett és a feltörekvő gazdaságokban. Hitelintézeti Szemle, 7. évf. 6. sz.

VÁRhegy Éva (1995): Bankok versenyben. Budapest, Pénzügykutató Rt.

VÁRHEGy I ÉvA (2002): Bankvilág Magyarországon. Budapest, Helikon Kiadó.

VÁrhegy Éva (2003): Bankverseny Magyarországon. Közgazdasági Szemle, L. évf., december.

VÁRHEGY ÉvA (2008): Sebezhetőség és hitelexpanzió a mai válság fényében. Antal László könyvének érvényessége. Hitelintézeti Szemle, 7. évf. 6. sz.

VÁRHEGY ÉvA (2010): A válság hatása a magyarországi bankversenyre. Közgazdasági Szemle, LVII. évf. október.

VÁRHEgy Éva (2011): Kettős szorításban: a magyar bankszektor kilátásai. Hitelintézeti Szemle, 10. évf. 1. sz.

VÁRhegy Íva (2011): Az OTP mint nemzeti bajnok. Külgazdaság, 55. évf. 7-8. sz. 